\title{
"I WISH TO BE SEEN IN OUR LAND CALLED ĀFRIKĀ" 'UMAR B. SAYYID'S APPEAL TO BE RELEASED FROM SLAVERY (1819)
}

\begin{abstract}
John Hunwick
NORTHWESTERN

While Muslims were forbidden to enslave Muslims, in Africa, in battles between Muslims and non-Muslims, sometimes the latter captured Muslims, and sold them to European/American ship crews, who were seeking slaves to take across to America and sell, since Americans could use Muslims as slaves. ${ }^{c}$ Umar b. Sayyid (or, more likely, $\mathrm{Sa}^{\mathrm{c}} \overline{\mathrm{i}} \mathrm{d}$ ) was captured in Futa Toro in 1806/7, exported, and sold as a slave in South Carolina. Later he was bought by the brother of a subsequent governor of North Carolina and lived with both of them for some thirty years. ${ }^{\circ}$ Umar had learned Arabic in Africa, but as an aging slave forgot some of the rules of the language. Nevertheless, in 1819 he wrote an Arabic document, translated below, in which he quotes many parts of the Koran and seeks return to his homeland in Africa. The Koranic passages surround his statement: "I wish to be seen in our land called Âfrikā". However, he was forced to stay in America until he died in 1864, long after writing an Arabic autobiography.
\end{abstract}

The small contribution that I wish to make to unravelling the enigma of the enslaved ${ }^{c}$ Umar b. Sayyid ${ }^{1}$ is to examine the second longest document he wrote - the Autobiography of 1831 being the longest. This earlier document, penned apparently in 1819, and preserved at the Andover Newton Theological Seminary (Massachusetts), is in fact a letter ad-

\footnotetext{
${ }^{1}$ In his Arabic writings ${ }^{~}$ Umar always writes this name as S-y-d, which must be read as Sayyid. In West Africa "Sayyid" is rarely used as a personal name, but rather as a title of respect, especially for a religious scholar. The letter "b." which separates 'Umar's name from his father's name is an abbreviation for the Arabic $i b n$ (son of). In English, ${ }^{\mathrm{C}}$ Umar was known in nineteenth-century writings about him as Omeroh, Moro, or Moreau, and his father's name was not given. ${ }^{~}$ Umar gives his mother's name as Umm Hānī Y-r-m-k; see Allen D. Austin, African Muslims in Antebellum America: A Sourcebook (New York,: Garland, 1984), document XI, and unnumbered document, p. 476. She had evidently died before ${ }^{\mathrm{C}}$ Umar was taken into slavery, since he used the phrase "may God cool [i.e., make pleasant] her tomb".
} 
dressed to his owner's brother, Major John Owen, and the Christian community of Raleigh (North Carolina), or perhaps the congregation of the church they attended. ${ }^{2}$ It consists largely of quotations, both from the Qur ${ }^{\circ} \bar{n}$ and from other texts that ${ }^{~}{ }^{\mathrm{N}}$ mar had apparently memorized, but buried in the middle of it is what seems to be an appeal for him to be released from slavery and returned to his homeland.

The selection of memorized texts that ${ }^{\mathrm{c}}$ Umar reproduces in this document repays study. We must assume that they neither represent the entirety of what he had memorized, nor do they represent an entirely random selection from his storehouse of memory. The question is, therefore, why did he choose this particular selection of texts? Is it possible to deduce some kind of logic behind the selection? What, indeed, was ${ }^{\mathrm{c}}$ Umar's purpose in recalling these texts from the recesses of his memory and weaving them into a document that no one, within his immediate circle but he, could read? Below is an exegesis of the various components of the text, though the suggestions made must be considered tentative, for clearly there can be no certainty about what was going on in 'Umar's mind when he wrote the document.

Let us begin by recalling the little we know about the chronology of 'Umar's life. He was born in Futa Toro (modern Senegal), in or about the year 1770. We can deduce this from what he says in his "Autobiography", written in 1831, where he states that he had been in America for twenty-four years, and that he left his country at the age of thirty-seven. He further states that in his youth in Africa he had studied (evidently in several locations) for twenty-five years and had then returned to his homeland, where he spent six years. This accounts for a total of thirtyone years out of the thirty-seven he lived in Africa before being captured. The remaining six years would have been the period of his childhood. Children normally begin memorization of the Qur ān at about the age of six. It probably took him six or seven years to complete memorization of the sacred text.

The remaining eighteen or nineteen years of study that he refers to would have been spent in the reading, and in many cases the memoriza-

\footnotetext{
2 The letter was sent as an accompaniment to a letter (dated 10 Oct. [?] 1819) from John Louis Taylor, Chief Justice, North Carolina, and vice-president of the Auxiliary Society of the American Colonization Society of Raleigh, North Carolina, to Francis Scott Key, in the hope that the latter could obtain a translation of it; see Austin, op. cit., 455. It is not clear how John Louis Taylor got hold of the letter, or why he thought Francis Scott Key could obtain a translation of it.
} 
tion, of other basic Islamic texts. This he achieved at the hands of several teachers whom he mentions in his Autobiography: Muhammad Sayyid, whom he appears to call his brother, i.e., Muhammad b. Sayyid, Sulaymān Kamba, and Jibrīl ${ }^{~}$ Abd Allāh, none of whom can at this stage be identified more precisely. His studies took place in his homeland of Futa Toro, an extensive region stretching for over two hundred miles along the middle Senegal River valley east from Dagana, and in the region of Futa Bundu, which lies along the west bank of the Faleme River, a tributary of the river Senegal. By the late eighteenth century Futa Toro had been united under the rule of Tukulor clerics into an Islamic state. ${ }^{3}$

However, to judge from ' ${ }^{\mathrm{c}}$ Umar's command of Arabic, or his ability to recall what he was taught in Africa, one might doubt that he had spent a full twenty-five years in the pursuit of knowledge. Even in 1819, some eighteen years after he claims to have completed a quarter of a century of study, his command of Arabic and his memory of texts, was imperfect; by 1831 it was manifestly more defective. In his autobiography in that year he states: "I am very forgetful of my own language and of Arabic. ... I have weak sight and a weak body. I know little grammar and little vocabulary." There is, for example in his Qur ānic quotations in the text of 1819 confusion of hamza and 'ayn, e.g., lā tu'ākhidhnā in nasi ${ }^{c} n \bar{a} a w$ $a k h t a^{c} n \bar{a}$ ("Do not punish us if we forget or make mistakes" [page 2, line 4]), instead of in nasīna aw akhta nāa; and shay ${ }^{c} a n$ for shay an (page 2,

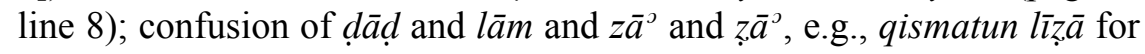
qismatun $\operatorname{diz}_{\bar{a}} \bar{a}$ (page 1, lines 7-8); confusion of $\sin$ and $\operatorname{sh} \bar{i}$, e.g., $s a^{c} n$, instead of $\operatorname{sh}^{\mathrm{D}} n$ (confusion here also of hamza and ${ }^{c} a y n$ ), and later $k h \overline{a s i} i^{c}$ an for $k h \bar{a} s h i^{c} a n$ (p. 2, line 14). There is also confusion of a whole word for another, e.g., wa-man așa for wa-man as $\bar{a}^{\jmath} a$ (page 2, line 6).

Perhaps this is not very surprising, in as much as the traditional method of learning the Qur ${ }^{\circ} \bar{a} n$ as a youth in West Africa was to write out a number of verses every day on a wooden board, memorize them, and then wash them off, so that a new set of verses could be written down. Only advanced students of the Qur ān learned all the complex rules of its orthography; ' Umar clearly did not pursue his education to this level. He wrote down what he wrote down in America based solely on what his ear recalled having heard, not what his eye might have recalled from a written text. ${ }^{4}$ Perhaps a more serious error on ${ }^{c}$ Umar's part was apparently to

\footnotetext{
3 See David Robinson, Chiefs and Clerics: The History of Abdul Bokar Kan and Futa Toro, 1853-1891 (Oxford: Oxford University Press, 1975), 10-27.

${ }^{4}$ In two of his Qur ${ }^{\circ} \bar{a}$ nic quotations final words are missing (page 1, end of
} 
attribute to the Qur ${ }^{\circ} \bar{a}$ (the Word of God) phrases that do not form part of it, e.g., the phrase "Whoever looks after the need of a believer, God will look after his need", repeated on page 2 in lines 7 and 9, onto which is then grafted a legitimate Qur ${ }^{\circ} a \bar{n} i c$ quotation. As we shall argue below, this hybridity certainly represents a message he wanted to get across, but it is (to say the least) a very unorthodox way of doing so.

Another example of aural memory failing to conform with visual memory is the one line he quotes (or at least the one line that can be clearly identified) from a non-Qur'ānic source. This is the opening line of a verse work on Arabic grammar, the Mulhat al-i ${ }^{c} r a \bar{b} b$ of al-Harīin (d. 1122). Abū Muhammad al-Qāsim b. ${ }^{c}$ Alī al-Harīīī was a philologist of Bașra, best known for his literary and linguistic tour de force, the Maqāmāt, a work of rhyming prose widely studied in West Africa. His Mulhat $a l-i{ }^{c} r a \bar{b} b$ is also widely used, competing with the Alfiyya of Ibn Mālik as a memorizable work on grammar. It opens: Aqūlu min $b a^{c} d i$

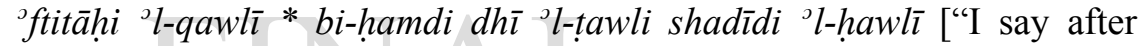
opening [my] speech with praise of the One possessed of mastery, the Mighty in Power"]. As remembered and rendered on paper by 'Umar b. $\mathrm{Sa}^{\mathrm{c}} \overline{1} \mathrm{~d}$ it reads on page 1, Aqūlu min $b a^{c} d\{i\}^{5}{ }^{\circ} \mathrm{ftah}\{i\}{ }^{\circ} \mathrm{l}$-qawlì $* b i$ hamd $\{i\}$ dhi tawlī sadìd\{i\} ' $l$-hawlì while on page 2 it reads, $A q \bar{u} l\{u\}$

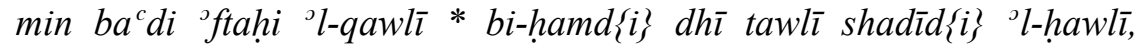
where the shin is correctly rendered. ${ }^{c}$ Umar departs from the rajaz meter of the original only in substituting ${ }^{J} \mathrm{ftah}$ for ${ }^{\mathrm{J}} \mathrm{ftita} h \mathrm{~h}$. The line of verse is used early on in the document to serve the purpose of making a transition from the initiatory praise of God in the opening line, the "name and address" of the person to whom the document is addressed: "Major John Owen and whosoever is with them from among the community of Christians in the place, town, called Rūlī [Raleigh]", and a short theological assertion: "And [God is] the First, the Unique without a beginning, and the Last, the Everlasting without an end", to what is presumed to be the substance of the document (though it is followed by other indecipherable lines of verse).

All of these above examples suggest that although ${ }^{\mathrm{C}}$ Umar had benefited from an Arabic education in his youth, he had not reached such heights as would have made him into a scholar in his own right. He was literate but not learned. This raises doubts as to whether he could have spent as much as twenty-five years solely in the pursuit of education, as

lines 8 and 9).

${ }^{5}$ Inflection vowels in braces are not in ${ }^{~}$ Umar's text. 
he appears to claim. In the Islamic tradition learning is regarded as a lifelong process; men in middle age will take their places in the circle of students of a respected shaykh without embarrassment. ${ }^{\circ}$ Umar, then, may well have pursued learning only intermittently after a certain age, perhaps in between periods spent earning a living. Nevertheless, he retained enough knowledge of Arabic apparently to be able to read the Arabic translation of the Bible he was given around the time he composed the document under scrutiny. Of course, we cannot be sure exactly how much of it he understood; the Islamic learning tradition was not simply to pick up a book and read it, but to learn how to read or recite it at the hands of a teacher, and then to have its content explained. ${ }^{c}$ Umar had no such help with the Bible. A document written in 1825 by someone who had evidently met with ${ }^{\mathrm{c}}$ Umar relates that some Africans considered him to be "a pray-God to the king", i.e., a marabout who would offer prayers on a ruler's behalf; however such a position does not require extensive learning, but rather a good memory for the Qur ${ }^{0} \bar{n} n{ }^{6}$

To return to the story of 'Umar's life, in 1807 (or possibly late in 1806) ${ }^{c}$ Umar was captured when an enemy army attacked the place where he was living, and was taken off to be sold into slavery. ${ }^{7}$ As he says in his Autobiography: "There came to our land a large army that killed many persons. It [=they] took me walking [to] K-bā (or K-b-y) ${ }^{8}$ the sea/river (yamsh $k$-ba $/ k-b-y$ al-bahr), they sold me into the hand of the Christian [who] bought [me], walk to the big ship in the big sea (or river), walk in the big sea a month and a half, then came to a place called Dhālustun [Charleston] ${ }^{9}$ in the speech of the Christian". As is evident from this passage - typical of the style of the Autobiography - ${ }^{c}$ Umar's command of written Arabic, some thirty years after he had completed his studies, and twenty-four years after he had been enslaved, was shaky. This we would not, perhaps, find very surprising. But, in point of fact, it

${ }^{6}$ See Austin, African Muslims in Antebellum America, 450, 461.

${ }^{7}$ Robinson, Chiefs and Clerics, 17, speaks of an invasion of Futa Toro by armies from Bundu and the Bambara state of Karta in 1806-7, bringing to an end the rule of ${ }^{\mathrm{c}} \mathrm{Abd}$ al-Qãdir Kan, almamy of Futa Toto since the death of Sulaymān Baal in the 1770s.

8 Vocalization omitted.

9 "Umar frequently represents a "dy" sound by the Arabic letter "dhâl"; he hears Charleston as Dyālston, then writes it as Dhālustun. In West Africa it is more common to find the letter " $z \bar{a}^{\lrcorner}$" representing the sound "dy" (e.g., the town of Dyakha [or Jaxa] is written Zāgha). In Arabic dialects dhāl is often transformed in to $z \bar{a}^{\text {ग }}$ (e.g. zamb for dhanb, "sin"). 
is difficult to judge how much his command of Arabic had deteriorated over the years, since in the document of 1819 he hardly writes anything that is not a quotation.

One of the few phrases of his own in that document, in fact, sheds some light on the interpretation of the sentence in the Autobiography cited above. On page 2, line 11, he says: "Indeed I wish to be seen ${ }^{10}$ in our land called Āfrikā in a place of the sea/river (al-bahrr) called K-bā (or K-bya ${ }^{11}$ )". In the first translation of the Autobiography the phrase yamsh $\bar{\imath}$-ba al-bahrr was evidently read as yamshī kabìr al-bahr, and despite the fact that this reverses a normal order of words it was correspondingly translated as "brought me to the great sea". ${ }^{12}$ In the hitherto only existing translation of the document of 1819 , the phrase " $f \grave{i}$ makān al-bahr yusammā $K$-bāa/K-bya - "in a place of the sea/river (al-bahr) called K-bā/K-bya" seems to have been read as fì makān al-Bawir yusamm $\bar{a}$ Kab $\bar{a}$, translated as "in a place called Kaba in Bewir", which is clearly wrong. ${ }^{13}$ This, in turn, gave rise to speculation by Allen Austin that "Kaba in Bewir" was "a city and country which is probably the gold country of Bure just west of the Niger between Bammako [sic] and Kankan and southeast of Bundu". ${ }^{14}$

That the K-bā of the Autobiography and the K-bā or K-bya of the 1819 document are one and the same location seems clear. The question is: can the location be identified? In both documents the place is associated with the word bahr, which means any large stretch of water, and is applied equally to a sea or to a large river (e.g., al-bahr al-ahmar - the Red Sea; bahr al-Nìl - the river Nile). A slave ship could in theory moor

${ }^{10}$ In fact, he makes an error here by using the 3rd person singular verbal forms: "he wished that he see", but he clearly intends to say "I wish that I am seen", or perhaps just "I wish to see". His use of the 3rd person singular when referring to the 1 st person is one of his erroneous stylistic habits throughout his Autobiography.

${ }^{11}$ The final letter can be read either as alif maqșüra or $y \bar{a}$. The shape of both letters is the same, and the two dots that distinguish $y \bar{a}^{\jmath}$ from alif maqșüra are generally omitted in handwriting.

${ }^{12}$ See "Autobiography of Omar ibn Said, Slave in North Carolina, 1831", American Historical Review 30, no. 4 (July 1925): 787-95, quoted in Austin, African Muslims in Antebellum America, 465.

13 Translation of Abdulla Basabrain (c. 1984) in Austin, op. cit., 515. The origins of this identification appear to lie in an interpretation given in an article published in the Missionary Herald (April 1869): 114-17, partially reproduced in Austin, op. cit., 484

${ }^{14}$ Austin, op. cit, 448. 
by the seashore or the bank of a river. There are, in fact, few mooring spots along the Senegalese coast except at the islands of St. Louis at the mouth of the river Senegal. In Wolof and Arabic St. Louis is known as Ndār, which could scarcely be transformed into K-bā/K-bya. On the other hand, much of the slave trade was conducted from along the banks of the river Gambia. Ocean-going vessels could navigate a good distance up river and smaller craft could penetrate even further into the interior of Africa along the river Gambia. It gave ideal access for slave purchasers to remote areas to which slaves could more easily be brought from the interior, and it also provided safe anchorage and access to food supplies. ${ }^{15} \mathrm{I}$ would suggest, therefore, that $\mathrm{K}-\mathrm{b} \overline{\mathrm{a}} / \mathrm{K}$-bya is to be read as $\mathrm{Ga}(\mathrm{n})$ biya. The Arabic letter $k \bar{a} f$ is regularly used to represent a hard "g" throughout the Sahara and the Sahel (e.g., Kāc $\mathrm{u}$ - Gao; Takānit Tagānit), so it is unproblematic to read K-bā/K-bya as G-bā/Gabya. If we then read the first syllable as nasalized, i.e., Gã, we arrive at Gãbya, which we have no difficulty in pronouncing as Gambia. The Arabic script has no way of showing nasalization, and different writers use different consonants to represent it (e.g., Ghum $=$ Kõ $=$ Kong in Ivory Coast), or simply omit it.

In the 1819 document, therefore, ${ }^{\mathrm{c}}$ Umar is expressing a wish to be taken back to the place from which he was initially shipped to America. For him, this location, the river Gambia, would have represented the gateway into the interior of Africa from which he could presumably find his way to Futa Bundu and eventually Futa Toro. He probably had no knowledge of the Senegalese Atlantic coast. The rest of the document is, in one sense, padding for this expressed wish, which is buried deep among Qur'ānic and other quotations. In using such quotations he not only "wraps" his sentiment in the language of God, but he uses the quotations to deliver some messages to his master and to his master's family and friends. Perhaps the fact that they cannot read what he writes is of no great importance. It is rather the inherent power of the words themselves that is of significance.

15 See Mungo Park, Travels in the Interior Districts of Africa, performed in the years 1795, 1796, and 1797, with an account of a subsequent mission to that country in 1805 (London: Printed for John Murray by William Bulmer and Co., 1816), 36ff. See also Michael A. Gomez, Exchanging Our Country Marks: The Transformation of African Identities in the Colonial and Antebellum South (Chapel Hill, NC: University of North Carolina Press, 1998), 72, 156; Douglas Grant, The Fortunate Slave: An Illustration of African Slavery in the Early Eighteenth Century (London and New York: Oxford U. P., 1968), passim. 
The document opens in traditional fashion with praise to God-God who created human beings so they might worship him, and so He might test their words and deeds in this world. ${ }^{16}$ Again, as one might expect in a letter, this is followed by an identification of the person or persons to whom the letter is addressed: Major John Owen and his Christian friends in Raleigh. Then comes an affirmation of the Muslim belief in the eternity of God: He is "the First, the Unique (al-Fard) without there being a beginning, and the Last, the Everlasting ( $a l-B \bar{a} q \bar{l})$ without there being an end". What follows is, perhaps, rather surprising, in that it is the opening line of a didactic poem on Arabic grammar, but it is the sentiment expressed which is the important thing here. It helps the writer to separate the initial formalities of the letter from what he actually wants to say. Hence he initiates the substance of the letter with the resounding phrase: "I say, after opening [my] speech with praise of the One possessed of mastery, the Mighty in Power". ${ }^{17}$ Unfortunately what follows seems to make little sense. The material appears to be set out as verse, but the two "verses" neither rhyme properly, nor can they be scanned.

This material is followed by a phrase that is repeated twice again in the document, and seems to be 'Umar's mantra: "Goodness comes from God, not from anyone else". ${ }^{18}$ One may read into this the notion that goodness or kindness is not to be expected from human beings, and if one experiences it then it is from God that it originates. Below this is a complex geometric figure of a type that he uses elsewhere in some of his writings. Inside it is written some Arabic that, as yet, can only partly be deciphered. What is clearly readable is the name "Jim Owen" (dhim $\left.{ }^{c} \bar{u} w-n\right)$ at the lower left, and the word shaykh (elder) followed by a word to be read $d h-b-l$, no doubt in error for $d h-n-l=j-n-l=$ "general" 19

What follows immediately after the geometric figure seems to be, as the translator Abdullah Basabrain perceived, ${ }^{20}$ some English words written in Arabic script. They are $n \bar{u} w-b-r f \bar{u}(\bar{a}) t \bar{i} n h-d-d n \bar{a} t \bar{i} .^{21}$ This would

\footnotetext{
16 For a full translation, see the latter part of this article.

17 In Arabic letters the opening prayers, praises and greetings are conventionally followed by the phrase: $w a-b a^{c} d-$ "next / thereafter".

$18 \mathrm{He}$ uses the first part of this phrase in another writing of his; see Austin, op. cit., document III.

19 See below, n. 31.

20 See Austin, op. cit, p. 514.

${ }^{21}$ It will be noted here that nasalized sounds have simply been suppressed, e.g., Nūwabar=Nuvãbar=November; h-d-d = hãdad = hundred. Basabrain gives: "November eighteen Sunday, nineteen". It is difficult to see how he read
} 
appear to be: November fourteen hundred nineteen, no doubt an error of English, since the date of writing was eighteen hundred (and) nineteen. There follows this odd "dating" the first of a series of Qur ānic quotations: "Is the male for you and the female for Him? That is then a division most unjust. What are they but names, which you and your ancestors bestowed on them, for which God sent down \{no authority\}? ... (53:21-23)" 22 The context of these verses is supplied by what immediately precedes them in the Qur ânic text, but which is omitted by 'Umar: "Have you considered al-Lāt and al- ${ }^{c} U z z \bar{a}$, and al-Manāt, the third, the other? (53:19-20)" The reference here is to three female deities whose shrines were all in the vicinity of Mecca. Originally what followed was the so-called Satanic verse: "Those are the exalted cranes whose intercession is to be expected; their likes are not to be neglected". The Prophet Muhammad is said to have been informed by the angel Gabriel that this verse, which seems to grant an intercessory status to three (female) deities, or idols was not a divine revelation, but an intervention from Satan, and the verses "Is the male for you and the female for Him? ..." were substituted. ${ }^{23}$ The three deities were collectively known as "the daughters of Allāh", and it is possible that the use of this quotation by "Umar was an implicit criticism of Christian doctrine, which attributes offspring — a son in this case — to God. The last part of the Qur'ānic quotation: "What are they but names which you and your ancestors bestowed on them, for which God sent down \{no authority\}?" could also be read as a distant criticism of Christian doctrine, implying that belief in subsidiary deities, such as ${ }^{c}$ Umar might have understood Jesus, the "son of God", or the Virgin Mary to be, had no divine sanction. It is even possible that ${ }^{\mathrm{c}} \mathrm{Umar}$ in some way equated the Christian notion of the Trinity with the trinity of goddesses (and, indeed, al-Lāt is nothing more than a feminine form of al-Lāh/Allāh).

These verses are immediately followed by the mantra: "Goodness comes from God, not from anyone else", and then by the first two verses of a Qur`ānic sūra, Sūrat al-Masad (no. 111): "May the two hands of Abū Lahab perish and may he perish. His wealth shall not benefit him, neither what \{he gained\}". These verses are used in talismans as a pow-

$f \bar{u}(\bar{a}) t \bar{t} n$ as "eighteen", unless he was sub-consciously influenced by the fact that the first numbers of the century had to be 18 not 14 . He clearly read $h-d-d$ as ahad $=$ Sunday.

22 The words in braces, here and below, are omitted by ${ }^{\mathrm{c}}$ Umar.

23 See W. Montgomery Watt, Muhammad: Prophet and Statesman ([London]: Oxford University Press, 1964), pp. 62-65. 
erful curse. They refer to an uncle of the Prophet, nicknamed "the flaming one ( $a b \bar{u}$ lahab)", perhaps because in the next two verses he is condemned to burn in the fire of Hell, because of his vociferous opposition to the Prophet's claims. Is this a subtle curse against ' Umar's captors, or against those who sold him on more than one occasion? The sentence "His wealth shall not benefit him, neither what \{he gained\}" may suggest an imprecation against those who grew rich from the selling of slaves.

What follows this is two lines (p. 1, 11. 10-11) that look, from the way they are laid out, like poetry. However, they do not rhyme, either with each other or internally, nor can any known Arabic meter be detected. Their origin has not been discovered. Is it possible that ${ }^{\mathrm{c}}$ Umar made them up? Or are they fragments of verses he (mis-)remembered strung together to give some meaning best known to him. They are certainly accusatory, and even condemnatory, asking if the person to whom they are addressed is mad or foolish, and stating that he has both black hair and a black heart. Did he, says the passage, consider if he might be blamed? Can we read this as a diatribe against those who inserted him into the world of slavery?

The second page of the letter opens with the same opening line of alHarīî̀'s Mulhat al-ic $r a \bar{b} b$ : "I say after opening [my] speech with praise of the One possessed of mastery, the Mighty in Power", followed by the mantra: "Goodness comes from God, not from anyone else". It is as if 'Umar by starting a new page is making a new start in his composition. This second page is dominated by Qur annic quotations, the first of which (2:285-6) contains two messages that we may think ${ }^{\mathrm{c}}$ Umar wished to direct to his master. The first part of this first quotation from the Qur ${ }^{\supset} \bar{a} n$ reads: "The Messenger [Muhammad] believed in what was sent down to him \{from his Lord, as did the believers. All believed in God\} and His angels and His books and His messengers. We make no distinction between any of His messengers." "Umar, in fact, omitted the words in braces, whether intentionally (which is doubtful), or by oversight. Perhaps the more important part of the above quotation is the last sentence of it: "We [God] make no distinction between any of His messengers", which we might interpret to be a message from ${ }^{c}$ Umar recognizing that God makes no distinction between His messenger Muhammad and his messenger Jesus (for the Qur ${ }^{\curvearrowright} \bar{a}$ treats Jesus as a divine messenger, as a prophet, and firmly denies that he is a "son of God"). So perhaps "Umar is trying to show his owner that they are religiously equal, since they are both followers of prophets who, in God's sight are equal. 
A different kind of message is conveyed in the second verse of the quotation: "God does not burden a soul with anything beyond its capacity to bear. It is rewarded for [the good] that it earns, and pays for [the evil] it commits. O our Lord, do not take us to task if we forget or fall into error. ${ }^{24} \ldots$ O our Lord, do not burden us with what we have no strength to endure, and pardon us and forgive us and have mercy on us. Thou art our Lord, so aid us against the unbelievers". Here is a prayer for himself, and an implicit warning to his owner. May God not place upon me burdens (i.e., of slavery) beyond what I am capable of bearing, and may He forgive my sins and pardon me. To his owner there is this warning: "[The soul] is rewarded for [the good] that it earns, and pays for [the evil] it commits". Therefore, do not overburden me or mistreat me, lest God punish you, but rather do good in my regard, so God may reward you. There is also a sting in the tail: "so aid us against the unbelievers", not necessarily, perhaps, a plea to God to help him revolt against his owner, but a broader plea for Muslims to be able to stand up against the injustices perpetrated upon them by Christians.

Further implicit encouragement to ${ }^{c}$ Umar's master to treat him well is contained in the next Qur'ānic quotation (41:46), the meaning of which is not obscure: "Whoever does a good deed, it shall be accounted in favor of his soul, and whoever commits evil, it shall be accounted against it”. Following this are two composite sentences containing Qur ānic quotations to which ${ }^{\mathrm{c}}$ Umar seems to have added the following introductory clause: "Whoever looks after the need of a believer, God will look after his need". The phrase sounds like a saying of the Prophet, though it has not been possible to trace it in the principal collections of hadith ${ }^{25}$ In both cases the phrase is seamlessly conjoined to a Qur ānic quotation relating to the Day of Judgment, promising that God will pay the doer of good special attention on that awful day: (1) Whoever looks after the need of a believer, God will look after his need 26 "on a day when a man shall flee from his brother and his mother and his father and his wife and his sons. Every man on that day shall have a matter that preoccupies him"; (2) Whoever looks after the need of a believer, God will look after

\footnotetext{
24 Omission in ${ }^{c}$ Umars text.

${ }^{25}$ For sayings with similar wording ascribed to the Prophet, see Abū Hājar

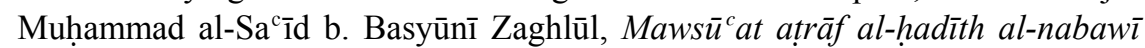

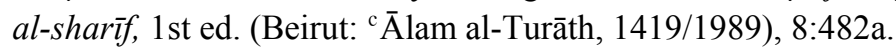

26 The quotation up to here does not form part of the Qurª̄n, whereas what follows represents 80:34-37.
} 
his need" 27 "on a day when no soul shall have power to do anything for another soul and the matter on that day shall belong to God". This is immediately followed by a further Qur ānic quotation, taken from a different sūra of the Qur'ān, but so placed that it seems in apposition to the preceding phrase, and again flows on seamlessly from it: "A day on which a man shall see what his hands have wrought and the unbeliever will say, 'Would that I were dust'". ${ }^{28}$ We may again read the reference to "the unbeliever" as an allusion to his master, and understand that 'Umar is again "threatening" him with divine punishment if he treats him badly. When he wrote these words he had been in the service of Jim Owen for ten years and had, at least nominally, converted to Christianity. However, the letter to John Owen should perhaps be seen as something of a talisman; that is to say, that by making such statements in the context of Qur ${ }^{\supset} \bar{a}$ nic verses, ${ }^{C}$ Umar hoped to ensure his future well-being through thick and thin.

Next comes the key sentence of the document following hard on these "warnings" and immediately preceding (at least part of $)^{29}$ the text of one of the most powerful süras in the Qur ān. This key sentence is itself preceded by what looks like a somewhat crudely drawn five-pointed star. But it is in fact a very powerful talismanic symbol, the pentacle, said to be the "seal of Solomon", and the first of seven "seals" that are frequently found in talismans or inscribed over doorways of buildings to protect them. ${ }^{30}$ It was no doubt drawn by ${ }^{c}$ Umar in this spot to invoke God's power. ${ }^{31}$ It is said to represent the secret 100th name of God and

27 The quotation up to here does not form part of the Qur ${ }^{\top} \mathrm{a} n$, whereas what follows represents 82:19.

${ }^{28}$ Qur $^{\circ} \bar{a} n$ 78:40. In another of his writings ${ }^{~}$ Umar engages in Qur $^{\circ} \bar{a} n i c$ hybridity when he inserts the last words of 61:13 after the first two words of süra 110; see Austin, op. cit., document XV. He writes: Idhā jā a ['l-]naṣru[n] mina 'llāhi wa-fathun qarībun, wa-bashshiri ${ }^{\circ}$ l-mu minīn instead of Idha ja $\bar{a}^{\circ}$ a nașru 'llähi wa l-fath. The document was written when he was eighty-four, and the error probably arose from a simple confusion of two Qur ${ }^{\circ}$ anic phrases both containing the words nașr and fath.

29 The text breaks off abruptly at the foot of page 2, at the beginning of verse 14 of Sürat al-Mulk (no. 67), out of a total of thirty verses. It would seem likely, therefore that there was (at least) one more page to the letter.

30 See Edmond Doutté, Magie \& religion dans l'Afrique du Nord (Algiers: A. Jourdan, 1908; reprint, Paris: J. Maisonneuve, 1984), 156-58.

${ }^{31}$ It is also drawn on an Arabic translation of the Lord's Prayer written out by ${ }^{\mathrm{c}}$ Umar; see Austin, op. cit., document VI. It appears twice on another of 
to have miraculous powers. ${ }^{c}$ Umar would certainly have needed a miracle to achieve his desire, which he explains in line 11 of page 2 , is "to be seen in our land called Āfrikā, in a place [on] the river called K-bā [Gambia?]". No such miracle was to be realized, though his covert appeals for kind treatment conveyed through verses of the "Book of God" were, indeed, effective, as we know that the remaining forty-five years of his life were spent in relative ease in the service of James Owen, and he was evidently a respected member of the local community, such that legend has credited him with qualities such as royal descent, which he manifestly did not possess.

\section{TRANSLATION}

\section{‘UMAR B. SAYYID’S LETTER TO JOHN OWEN (1819)}

\section{Page 1}

1. Praise be to God who created creatures in order to worship Him, so that he might put to the test their deeds and their words, ${ }^{32}$ and their circumstances in the world.

2. Conveyance of greeting to Major John Owen ${ }^{33}$ and whosoever is with them from among the community of Christians in the place, town, ${ }^{34}$ called

3. Rūli [Raleigh]. And [God] is the First, the Unique without a begin-

'Umar's documents (a copy of Psalm 23), once with his name written inside it; see Austin, op. cit., 507, plate B.

32 This phrase is also used at the beginning of a copy of the Lord's Prayer written out by ${ }^{\mathrm{C}} \mathrm{Umar}$, reportedly in 1840 ; see Austin, op. cit., document X. It is likewise found in an undated document of which only a fragment is reproduced in Austin, op. cit., 507, plate C.

${ }^{33}$ In the Arabic script this is written: $m-y-d h d h-w-n{ }^{c} \bar{u}^{-}{ }^{\circ}-n$. The Arabic letter $d h \bar{a} l$ is clearly to be read as " $\mathrm{j}$ ". In the Autobiography "Umar uses the same letter for "ch", which he doubtless heard as "j" (i.e., Jālustun = Charleston). Hence we can supply the vowels for the first word to get mayja, i.e., "Major". $D h-w-n$ is to be read $D h \bar{u} n=J \bar{u} n$, i.e., John, and appears again in this form in the Autobiography and in a list ' Umar wrote of Jim Owen's family (see Austin, op. cit., document VII), and ${ }^{c} \bar{u}^{-}{ }^{D}-n$ as ${ }^{c} \bar{u}^{3} i n$, i.e., Owen. John Owen was the brother of James (Jim) Owen, 'Umar's master, and was later governor of North Carolina, December 1828 - December 1830.

34 "Umar uses a transcription of the English word "town" $(t-w-n=t a w n)$. 
ning, and the Last, the Everlasting without an end. "I say after opening [my] speech

4. with praise of the One possessed of mastery, the Mighty in Power": 35 . . . . . . . . . . . . . . . . . [illegible]

5. . . . . . . . . . . . . . . [illegible] Goodness comes from God, not from anyone else.

6. [Geometric design ${ }^{36}$ with writing inside it, including the title and name Shaykh $\left.D h-b-l / J-b-l^{37}\right]$ Jim Owen, $\left.{ }^{38}\right]$

7. November 1419 (i.e. 1819). "Is the male for you and the female for Him? That is then a division

8. most unjust. What are they but names which you and your ancestors bestowed on them, for which God sent down \{no authority\}?"39

9. Goodness comes from God, not from anyone else. "May the two hands of Abū Lahab perish and may he perish. His wealth shall not benefit him, neither what $\{$ he gained $\} " 40$

10. I ask you by God, O you who have grown gray-haired, what do you expect? * Have you reflected, $\mathrm{O}$ my brother, upon blame? ${ }^{41}$

11. Or are you mad or are you foolish? * And your hair and your heart are both black.

35 This is the opening line, somewhat corrupted, of a poem on Arabic grammar, the Mulhat al-i $i^{c} r \bar{a} b$ of al-Harīīi (d. 1122), a popular textbook in West Africa.

${ }^{36}$ An identical design appears in two other documents-both lists of members of the Owen family, reproduced in Austin, op. cit., document VI and plate A on p. 506.

37 The letters $d h / j-b-l$ were apparently written in error for $j-n-l$ (a dot being placed below the middle letter rather than above it). This could then be read: jin $[r] a l=$ "general". James Owen was a commander in the state militia, and in the War of 1812 had been Adjutant General; see Austin, op. cit., 447, 509-10, n. 6. The form $d h-n-l$ is used in another document where mention is made of Mista Dhin-l ${ }^{c} \bar{u}^{\mathrm{s}}$ in (Mister General Owen) in a list of members of that family; see Austin, op. cit., 506, plate A, and in the Autobiography, where it is clearly vocalized dhinal.

${ }^{38} \mathrm{Dh}-y-m^{{ }^{C}-}{ }^{-}{ }^{\mathrm{D}}-n$, i.e. Jim [James] Owen (1784-1865), ${ }^{\mathrm{C}}$ Umar's master.

${ }^{39}$ Qur ān, 53:21-23. Words in braces omitted in 'Umar's text.

40 Qur ${ }^{\circ} \overline{\mathrm{a}}, 111: 1-2$. Words in braces omitted in 'Umar's text.

41 The symbol * marks the division between two hemistichs in a verse of poetry. Lines 10 and 11 are written out like verse, though they do not fit a regular meter. 


\section{Page 2}

1. "I say after opening [my] speech with praise of the One possessed of mastery, the Mighty in Power". Goodness comes from God,

2. not from anyone else. "The Messenger believed in what was sent down to him \{from his Lord, as did the believers. All believed in God $\}^{42}$ and His angels and His books and His messengers. We make no distinction

3. between any of His messengers. And they say, "We hear and we obey. [Grant us] Thy forgiveness, O our Lord, for towards Thee is the [final] journey. God does not burden a soul

4. with anything beyond its capacity to bear. It is rewarded for [the good] that it earns, and pays for [the evil] it commits. O our Lord, do not take us to task if we forget or fall into error. ${ }^{43}$... O our Lord,

5. do not burden us with what we have no strength to endure, and pardon us and forgive us and have mercy on us. Thou art our Lord, so aid us against

6. the unbelievers." 44 I heard the saying of God Most High, "Whoever does a good deed, it shall be accounted in favor of his soul, and whoever commits evil, it shall be accounted against it". ${ }^{5}$

7. I heard the saying of God Most High, "Whoever looks after the need of a believer, God will look after his need ${ }^{46}$ 'on a day when a man shall flee from

8. his brother and his mother and his father and his wife and his sons. Every man on that day shall have a matter that preoccupies him"." ${ }^{47}$

9. I heard the saying of God Most High, "Whoever looks after the need of a believer, God will look after his need" 48 'on a day when no soul shall have power to do anything for another soul

\footnotetext{
42 Words in braces omitted in ' Umar's text.

43 'Umar omits here a sentence that begins with the same words as that following.

${ }^{44}$ Qur $^{\circ} \bar{a} n, 2: 285-86$, the last two verses of the second sūra of the Qur ${ }^{` a}$ n.

${ }^{45}$ Qur $^{\circ} \bar{a} n, 41: 46$. This phrase is also used at the beginning of a copy of the Lord's Prayer written out by ${ }^{\mathrm{c}}$ Umar, reportedly in 1840; see Austin, op. cit., document $\mathrm{X}$.

46 The quotation up to here does not form part of the Qur ${ }^{\circ} \bar{a} n$, whereas what follows does.

${ }^{47}$ Qurª̄n, 80:34-37.

48 The quotation up to here does not form part of the Qur ${ }^{\circ} \bar{a} n$, whereas what follows does.
} 
10. and the matter on that day shall belong to God". 49 "A day on which a man shall see what his hands have wrought and the unbeliever will say, 'Would that I

11. were dust" .50 [Pentacle] I wish to be seen in our land called Āfrikā, in a place [on] the river called K-bā / K-b-y.

12. "Blessed is He in whose hand is Dominion, and He has Power over all things. He who created death and life that you might be tested to see which of you

13. has performed best, and He is the Mighty, the Pardoner. He who created the seven heavens in layers. You see not in the Merciful One's creation any

14. disharmony. Look back again, then, do you see any flaw? Return your gaze yet again and again; it will return to you weakened and

15. enfeebled. We adorned the lower heaven with lamps and made them objects to be cast at the demons, for whom we prepared a punishment

16. of flames. And for those who disbelieved in their Lord is a punishment of Hell. What a terrible end! When they are cast in it they shall hear it

17. roaring as it wells up, almost bursting with fury. Whenever a group is cast therein its keepers shall ask them,

18. 'Did no warner come to you?' They shall say, 'Yes, a warner came, but we did not believe and we said, "God did not send anything down. You are

19. simply in great error"'. And they will say, "If we had listened or heeded we would not be dwellers in the Blaze'.

20. And they confessed their sin, but far removed [from God's mercy] are the dwellers in the Blaze. Those who fear their Lord in the Unseen shall enjoy

21. forgiveness and a great reward. Speak secretly or openly; God knows what is in your hearts. ${ }^{51}$

${ }^{49}$ Qur āan, 82:19.

${ }^{50}$ Latter part of Qur ${ }^{\bar{a} n}, 78: 40$.

${ }^{51}$ Qur ${ }^{p} a \bar{n}, 67: 1-13$. The text continues with the single Arabic word ${ }^{c} a l \bar{a}$, perhaps an error for $a l \bar{a}$, which is the first word of the following Qur ānic verse. In his Autobiography ${ }^{\circ}$ Umar quotes the entire sūra as a sort of prelude to the account of his life. There he correctly writes Alā [yaclam man khalaq]. 